Influence of Orchard Floor Management and Compost Application Timing on Nitrogen
Partitioning in Apple Trees

\author{
Dan TerAvest ${ }^{1}$ \\ Department of Crop and Soil Sciences, Washington State University, 201 \\ Johnson Hall, P.O. Box 646420, Pullman, WA 99164-6420
}

Jeffrey L. Smith

U.S. Department of Agriculture-Agricultural Research Service Land Management and Water Conservation, 215 Johnson Hall, P.O. Box 646421, Pullman, WA 99164-6421

\section{Lynne Carpenter-Boggs}

Center for Sustaining Agriculture and Natural Resources, Washington State University, 201 Johnson Hall, P.O. Box 646420, Pullman, WA 99164-6420

Lori Hoagland

Department of Crop and Soil Sciences, Washington State University, 201 Johnson Hall, P.O. Box 646420, Pullman, WA 99164-6420

David Granatstein
Center for Sustaining Agriculture and Natural Resources, Washington State
University, 1100 N. Western Ave., Wenatchee, WA 98801

John P. Reganold

Department of Crop and Soil Sciences, Washington State University, 201 Johnson Hall, P.O. Box 646420, Pullman, WA 99164-6420

Additional index words. Organic agriculture, nitrogen partitioning, dry weight partitioning, living cover, wood chip mulch, orchard legume, fertilizer efficiency

\begin{abstract}
Synchronizing the supply of plant-available nitrogen (N) from organic materials with the $\mathrm{N}$ needs of apple trees is essential to cost-effective organic apple production. Tree growth and organic matter mineralization are affected by orchard floor management. This study examines the effects of three orchard floor management systems, cultivation, wood chip mulch, and a legume cover crop, on the accumulation and partitioning of compost-derived $\mathrm{N}$ in young apple (Malus domestica Borkh.) trees at different compost application dates across two growing seasons. Compost enriched with ${ }^{15} \mathrm{~N}$ was applied to apple trees in April, May, and June of 2006 and 2007, and trees were excavated in Sept. 2007 to determine the fate of labeled compost $\mathbf{N}$. Trees with wood chip mulch had significantly greater dry weight and $N$ accumulation in vegetative tree components than trees with cultivation or legume cover. Fruit yields were similar between cultivation and wood chip treatments despite less vegetative growth under cultivation, as these trees partitioned more dry weight into fruit $(44 \%)$ than wood chip mulch trees (31\%). Nitrogen-use efficiency by trees was lower with a living legume cover crop than in other treatments due to competition for resources. In the cover crop aboveground biomass, $20 \%$ to $100 \%$ of the $\mathrm{N}$ was derived from compost. In comparison, only $5 \%$ to $40 \%$ of $\mathrm{N}$ in the decomposing wood chip mulch originated from compost. Tree reserves were an important source of $\mathrm{N}$ for spring fruit and leaf growth in all treatments, but significantly more so for trees in the cultivation treatment. Fruit and leaves were strong sinks for compost $\mathrm{N}$ early in the season, with trees allocating $72 \%$ of spring $\mathrm{N}$ uptake into leaves and fruit. In the summer, $\mathrm{N}$ uptake increased improving compost N-use efficiency. Summer $N$ was preferentially allocated to perennial tissues $(71 \%)$, bolstering $\mathbf{N}$ reserves. Trees with wood chip mulch performed well and had greater capacity to build $\mathrm{N}$ reserves, making wood chips ideal for establishing young organic apple orchards. However, as the orchard matures, it may be beneficial to switch to a groundcover that reduces tree vegetative growth.
\end{abstract}

Organic apple production has experienced significant growth in the past 15 years, largely due to food and environmental safety concerns regarding synthetic pesticides and

fertilizers used in conventional production. Increased organic fruit production can also be attributed to advancements in organic production practices, such as pheromone mating disruption for codling moth (Cydia pomonella), and yet significant challenges remain (Delate et al., 2008). Among the most significant challenges is nitrogen $(\mathrm{N})$ supply because organic fertilizers are often bulky and expensive, and release of $\mathrm{N}$ can be slow and unpredictable. Improving the understanding of $\mathrm{N}$ cycling in organic systems and increasing organic fertilizer-use efficiency are critical to cost-effective organic fruit production.

Cultivation in the tree row is currently the most common understory management practice in organic apple production. Cultivation provides weed control but is costly and impairs soil quality and $\mathrm{N}$ availability (Cambardella and Elliot, 1992; Granatstein, 2004; Sanchez et al., 2007). Alternative groundcover strategies that reduce costs and improve $\mathrm{N}$ mineralization of organic fertilizers are needed. Possible groundcovers include organic mulches and leguminous cover crops.

The use of organic mulches such as wood chips, shredded paper, or alfalfa have increased soil $\mathrm{N}$ availability and mineralizable forms of $\mathrm{N}$ in multiple studies (Forge et al., 2003; Marsh et al., 1996; Sanchez et al., 2003; Yao et al., 2005). Elevated soil N availability may result from increased microbial activity and $\mathrm{N}$ turnover (Forge et al., 2003; Yao et al., 2005). Forge et al. (2003) reported that use of a high $\mathrm{C}: \mathrm{N}$ ratio mulch in the tree row of an apple orchard did not result in net $\mathrm{N}$ immobilization or lower $\mathrm{N}$ supply and, to the contrary, increased $\mathrm{N}$ fertilizeruse efficiency. Neilsen et al. (2003) observed increased apple tree vigor and yield with organic mulches. In a comparison study of different orchard floor management systems, Shribbs and Skroch (1986) observed that apple trees under organic mulches had larger trunk diameter after four years compared with bare ground, cultivation, or a legume cover crop.

Sanchez et al. (2003) and Hoagland et al. (2008) reported that leguminous cover crops resulted in greater soil $\mathrm{N}$ availability and microbial activity than other orchard floor management strategies, including cultivation and wood chip mulch. Numerous studies, however, have reported reduced tree growth and yield due to increased competition between trees and cover crops (Hoagland et al., 2008; Larsson et al., 1997; Sanchez et al., 2003).

It is critical to ensure that $\mathrm{N}$ is supplied at the appropriate times to achieve adequate tree growth and yield. In-season $\mathrm{N}$ uptake and reserve $\mathrm{N}$ stored in perennial tissues (i.e., branches, trunk, and roots) from previous growth cycles are vital to apple tree nutrition. In late summer and autumn, trees move $\mathrm{N}$ from annual tissues to perennial tissues (Millard and Thompson, 1989; Neilsen et al., 2001b; Sanchez et al., 1992; Toselli et al., 2000). For instance, before leaf abscission, 35\% to $70 \%$ of leaf $\mathrm{N}$ is relocated into perennial tissues as reserve N (Blasing et al., 1990; Munoz et al., 1993). Remobilization of these reserves from woody tissues is the main driver of early season fruit and leaf growth, and has been correlated with leaf canopy development 
(Cheng and Fuchigami, 2002; Khemira et al., 1998; Millard and Neilsen, 1989; Neilsen et al., 2001a; Titus and Kang, 1982).

Partitioning of in-season $\mathrm{N}$ uptake is affected by fertilizer timing. Early season $\mathrm{N}$ uptake is heavily partitioned into fruit and leaves (Cheng and Fuchigami, 2002; Khemira et al., 1998). Munoz et al. (1993) reported that $\mathrm{N}$ uptake in April was preferentially partitioned into fruit, whereas May $\mathrm{N}$ uptake was allocated into leaves of peach trees, with vegetative growth being greatest from May to August. Fertilizer $\mathrm{N}$ application during this period of vegetative growth can result in higher fruit $\mathrm{N}$ concentrations, having possible detrimental affects on fruit quality and storage (Sanchez et al., 1992; Toselli et al., 2000).

Previous mulching and cover cropping studies have focused on tree and soil responses but have not examined their effects on internal $\mathrm{N}$ cycling. Conversely, $\mathrm{N}$ partitioning and uptake studies have centered on inorganic fertilizer use and application timing. Interactions between $\mathrm{N}$ partitioning, organic fertilizers, and orchard floor management are not well understood. The objectives of this study were to determine the effects of cultivation, wood chip mulch, and a legume cover crop on tree growth, partitioning of compost $\mathrm{N}$ at different application timings, and fertilizer-use efficiency.

\section{Materials and Methods}

Study site. This study was established in Spring 2005 at the Wenatchee Valley College-Auvil Teaching and Demonstration Orchard in East Wenatchee, WA. Soil at the study site is a Pogue sandy loam (coarseloamy over sandy or sandy-skeletal, mixed, superactive, mesic Aridic Haploxerol), averaging $1 \%$ to $2 \%$ organic matter with a $\mathrm{pH}$ of 7.0. Annual rainfall at the orchard site averages $21.6 \mathrm{~cm}$. The study site was previously planted to sweet cherry; after stump removal and disking, apple trees (cv. Piñata on M.7 EMLA rootstock) were planted at a spacing of $1.5 \times 4 \mathrm{~m}$ (1541 trees per hectare). This study was part of a larger experiment in which plots were arranged in a completely randomized block design with three replicates. Each plot consisted of a row of eight trees; only the interior six study trees were used for measurements. Trees were irrigated as needed throughout the growing season with undertree microsprinklers (R-10 rotators; Nelson Irrigation, Walla Walla, WA).

Orchard floor treatments and $N$ amendments. Three orchard floor manage-

Received for publication 25 Nov. 2009. Accepted for publication 14 Feb. 2010.

We would like to thank the reviewers for constructive comments that added significant meaning to this article. A special thanks to Tim Righetti for pointing out and teaching us about ratio-based responses and for his elegant examples with our data.

${ }^{1}$ To whom reprint requests should be addressed; e-maildteravest@wsu.edu. ment systems were selected for this study: mechanical cultivation, wood chip mulch, and legume cover crop. Each of these three treatments was applied to a $1.5-\mathrm{m}$ strip centered on the tree row. A 2.5-m drive alley planted to perennial grass was established between tree rows. Mechanical cultivation (CLT) using a Wonder Weeder (Harris Manufacturing, Burbank, WA) was done four times per season on the sides of the tree, with rototilling between the trunks as needed for weed control, disturbing only the upper 8 to $10 \mathrm{~cm}$ of soil. Wood chip mulch (WC) plots received a $15-\mathrm{cm}$ layer of mixed conifer and deciduous wood chips $(1.3 \times 2.5 \mathrm{~cm}$ maximum size) applied every spring. In 2005 and 2006, weeds were hand pulled, and in 2007, glyphosate ( $1 \%$ solution) was spot sprayed as needed to control weeds. Legume cover crop (LC) plots were established in May 2005 using a mix of Mt. Barker subterranean clover (Trifolium subterraneum), black medic (Medicago lupulina), burr medic (Medicago polymorpha), birdsfoot trefoil (Lotus corniculatus), and Colonial bentgrass (Agrostis tenuis). The drive alley and legume cover crop were mowed as needed, with clippings left on the ground.

In Spring 2005, pelleted chicken manure (NutriRich; Stutzman Farm, Canby, OR; 4\% N) was broadcast in the tree rows at a rate of $111 \mathrm{~kg}$ total N/ha and incorporated before tree planting. Due to poor initial tree growth, a soluble $\mathrm{N}$ fertilizer of fermented plant and animal waste (Biolink, Westbridge Ag Products, Vista, CA; $14 \%$ N) was injected below each tree at $36 \mathrm{~kg}$ total N/ha in mid-July. An additional $2.75 \mathrm{~kg}$ total $\mathrm{N} /$ ha was applied at weekly intervals throughout the summer as a foliar application of fish emulsion and kelp (Mermaids; I.F.M., Wenatchee, WA; Acadian Seaplants; Dartmouth, Nova Scotia, Canada).

In 2006 and $2007,101 \mathrm{~kg}$ of available N/ ha/year (200 kg total N/ha/year) was applied in three split applications (Apr. 7, May 9, and June 7, 2006 and Apr. 24, May 25, and June $21,2007)$ of Nielsen's chicken manure compost (Mossyrock, WA; 3.5\% N, 51\% available in a 14-d anaerobic incubation). Compost was spread in a band around the base of each tree 15 to $30 \mathrm{~cm}$ from the trunk. At each compost $\mathrm{N}$ application date in 2006 and 2007, one tree in each plot was treated with ${ }^{15} \mathrm{~N}$ (ammonium sulfate)-enriched compost. Forty-eight hours before application, compost for each tree was spread on a plastic sheet, sprayed with $5 \mathrm{~g}$ of $\left(\mathrm{NH}_{4}\right)_{2} \mathrm{SO}_{4}\left(\approx 70 \mathrm{~A} \%{ }^{15} \mathrm{~N}, 0.8 \mathrm{~g}{ }^{15} \mathrm{~N}\right.$ per tree $)$ dissolved in $50 \mathrm{~mL}$ of distilled water and incubated at room temperature until application. All of the $\mathrm{N}$ amendments used, except the ${ }^{15} \mathrm{~N}$-enriched ammonium sulfate, were organically certified. For this reason, the organic certification was removed from the study site.

Soil and groundcover sampling and analysis. Starting 1 month after application of ${ }^{15} \mathrm{~N}$-enriched compost, samples of soil, wood chip duff, and cover crop residue were taken $\approx 15 \mathrm{~cm}$ from the base of each tree. Samples were then taken monthly on May 9, June 7, July 13, and Sept. 29 in 2006 and May 23, June 19, July 19, and Sept. 23 in 2007. Soil samples were composites of three cores taken with a $2-\mathrm{cm}$ diameter probe to a depth of 10 $\mathrm{cm}$. Cover crop residue samples were composites of all aboveground biomass from three $7.4 \times 10-\mathrm{cm}$ areas. Wood chip duff samples were taken by clearing away intact wood chips and taking three samples of $\approx 20 \mathrm{~g}$ of decomposed wood chip litter. Soil and wood chip samples were sieved to pass through a $2-\mathrm{mm}$ sieve. All samples were oven dried, rollerground, and analyzed for ${ }^{15} \mathrm{~N}$ enrichment using an isotope ratio mass spectrometer (Thermo Finnigan, Germany) and total $\mathrm{N}$ and $\mathrm{C}$ using a dry combustion analyzer (Costech, CA).

Fruit harvest and tree excavation. In 2006, blossoms were removed to prevent fruiting. In 2007, fruit were hand thinned to five fruit per $\mathrm{cm}^{2}$ trunk cross sectional area (TCSA). Fruit were harvested on 15 Sept. 2007 from the center six trees of each plot. Thirty fruit per tree were randomly selected and sliced radially into eight sections. Two opposing eighths per apple were ground into slurry using a food processor, oven-dried at $105{ }^{\circ} \mathrm{C}$ for $72 \mathrm{~h}$, roller-ground, and analyzed for ${ }^{15} \mathrm{~N}$ and total $\mathrm{N}$ and $\mathrm{C}$.

All six sample trees per plot were excavated on 24 Sept. 2007. Trees were stripped of leaves by hand and then pulled out with an excavator; soil in the root zone was sifted using pitchforks to recover remaining roots. Each tree was separated into roots (below the graft union), new growth (2007 shoots), and frame (trunk + previous season branches). Frame fresh weight was measured in the field, after which tree frames were ground in a wood chipper and $\approx 500 \mathrm{~g}$ of wood chips were subsampled, oven-dried, and weighed to determine percentage of moisture. Frame subsamples, new growth, roots, and leaves were oven-dried, weighed, ground with a Wiley mill, roller-ground, and analyzed for ${ }^{15} \mathrm{~N}$ and total $\mathrm{N}$ and $\mathrm{C}$.

Calculations and statistical analyses. Calculations were done using the following equations:

Shoot: root ratio: $\frac{\text { Frame }(\mathrm{g})+\text { new growth }(\mathrm{g})}{\operatorname{Root}(\mathrm{g})}$

Nitrogen accumulation: dry weight $(\mathrm{g}) \times$ $\mathrm{N}$ concentration $(\%)$

Nitrogen derived from compost (NDFC \%) :

$$
\frac{\text { soil or tissue atom } \%{ }^{15} \mathrm{~N} \text { excess }}{\text { compost atom } \%{ }^{15} \mathrm{~N} \text { excess }} \times 100
$$

Nitrogen utilization, the proportion of available compost $\mathrm{N}$ present in the tree at excavation:

$\mathrm{N}$ utilization $\%=$

$$
\frac{\% \text { NDFS } \times \text { total tree } \mathrm{N}(\mathrm{g})}{\text { Rate of } \mathrm{N} \text { application }(\mathrm{g})} \times 100
$$

Statistical analyses were conducted using SAS 9.1 software (SAS Institute, Cary, NC). 
Accumulation and partitioning of dry weight and $\mathrm{N}$ in tree components between treatments were analyzed using one-factor analysis of variance (ANOVA). Because it is possible that partitioning may vary with tree size (Righetti et al., 2007), we tested the main variables with a covariate model after testing for homogeneity of slopes using a GLM model (Systat, 2004, version 11.00.01; Systat Software Inc., Richmond, CA). Soil and tissue NDFC and N utilization were analyzed using two-factor ANOVA, separately for each year, with orchard floor treatment and month as factors. Nitrogen derived from compost in cover crop residue and wood chip mulch was analyzed using two-factor ANOVA with year and month as factors. Simple-effect comparisons were used when an interaction was present. Mean separation was considered significant at $P \leq 0.05$ using a protected LSD.

\section{Results}

At excavation, tree dry weight and $\mathrm{N}$ accumulation were significantly different among orchard floor treatments (Table 1). Trees with WC had the greatest dry weight and $\mathrm{N}$ accumulation followed by CLT then LC. Frame, new growth, and leaf dry weight was greater in WC than in CLT or LC. The shoot:root ratio was significantly lower in CLT (6.3) and LC (6) trees than WC (9.6). Fruit dry weight was similar in CLT and WC, which both produced more than twice as much fruit dry weight as LC. Total $\mathrm{N}$ was greater in WC than in CLT or LC for roots, frame, new growth, and leaves. Nitrogen concentration was greater in roots but lower in new growth of WC compared with CLT and LC (Table 1). There were no significant treatment differences in the $\mathrm{N}$ concentration of frame, leaves, or fruit. Leaf $\mathrm{N}$ concentration in each treatment was adequate (greater than $2.2 \%$ ) for young fruit bearing apple trees (Stiles, 1994).

Trees under CLT partitioned a larger proportion of dry weight and $\mathrm{N}$ into fruit than WC or LC trees (Table 2). More than $44 \%$ of dry weight and $\mathrm{N}$ was allocated to fruit under CLT, whereas only $32 \%$ and $30 \%$ of dry weight and $25 \%$ and $26 \%$ of $\mathrm{N}$ were allocated to fruit under LC and WC, respectively. Trees in LC generally partitioned more $\mathrm{N}$ into roots and frame, while WC trees had a significantly larger proportion of dry weight and $\mathrm{N}$ in new growth and leaves. Covariate analysis indicated that tree size did not affect dry weight or $\mathrm{N}$ partitioning into individual tree components.

By the time of tree excavation in Sept. 2007 , the proportion of tree $\mathrm{N}$ derived from compost applied in 2006 was significantly lower than $\mathrm{N}$ originating from 2007 compost applications (Fig. 1). Averaged across all three application dates for each year, percentage of tree $\mathrm{N}$ derived from compost was greater in CLT trees in 2006 and lesser in WC in 2007 compared with other treatments. There were no significant differences among application dates in 2006, whereas in 2007, tree $\mathrm{N}$ originating from the April compost application was significantly lower than from the May and June applications.

There was statistical interaction between orchard floor management and application date for utilization of $\mathrm{N}$ from 2006 compost. Significantly more compost $\mathrm{N}$ was recovered in WC trees than other orchard floor management treatments in April, whereas in May and June, more compost $\mathrm{N}$ was recovered under cultivation than legume cover (Fig. 2). In 2007, compost $\mathrm{N}$ recovered in $\mathrm{WC}$ and CLT trees was greater than LC trees when averaged across all application dates. Compost $\mathrm{N}$ utilization was notably lower $(P \leq$ 0.1) for April-applied compost compared with the June application.

Allocation of compost $\mathrm{N}$ to tree components was, much the same as total $\mathrm{N}$, influenced by application timing as well as orchard floor management (Table 3). Compost $\mathrm{N}$ was preferentially allocated into fruit
(42\%) under CLT, whereas WC partitioned more compost $\mathrm{N}$ to leaves and new growth (together, 38\%) and LC partitioned more compost $\mathrm{N}$ into roots (13\%). In 2007, trees received compost $\mathrm{N}$ from three applications, April, May, and June, as well as reserve N from 2006 compost applications. Reserve N was taken up by trees in 2006 and then partitioned into storage organs over winter, becoming available for remobilization in early Spring 2007, or remained in soil $/ \mathrm{com-}$ post over winter and was then taken up by trees in 2007. At excavation, trees had mobilized nearly equal portions of reserve $\mathrm{N}$ into fruit $(32 \%)$, leaves + new growth $(32 \%)$, and roots + frame $(36 \%)$, averaged across all treatments. Of the Apr. 2007 compost application, $73 \%$ of $\mathrm{N}$ was allocated to leaves and fruit, and $27 \%$ into woody tissues. Conversely, only $29 \%$ of June compost $\mathrm{N}$ was allocated to leaves and fruit, with $71 \%$ being partitioned into woody tissues.

Table 1. Dry weight, N accumulation, and N concentration in tree components of 'Pinata'/M7 apple trees after three growing seasons (at excavation). Numbers within the same column followed by the same letter are not significantly different $(P \leq 0.05)$.

\begin{tabular}{|c|c|c|c|c|c|c|}
\hline & Roots & Frame & New Growth & Leaves & Fruit & Total \\
\hline Treatment & \multicolumn{6}{|c|}{ Dry wt (g/tree) } \\
\hline Cultivation (CLT) & $304 \mathrm{a}$ & $1495 \mathrm{~b}$ & $90 \mathrm{~b}$ & $310 \mathrm{~b}$ & $1717 \mathrm{a}$ & $3917 b$ \\
\hline Wood chip mulch (WC) & $371 \mathrm{a}$ & 2964 a & $496 \mathrm{a}$ & $874 \mathrm{a}$ & $1930 \mathrm{a}$ & $6648 \mathrm{a}$ \\
\hline \multirow[t]{2}{*}{ Legume cover (LC) } & $230 \mathrm{~b}$ & $1178 \mathrm{~b}$ & $107 \mathrm{~b}$ & $256 \mathrm{~b}$ & $883 \mathrm{~b}$ & $2654 \mathrm{c}$ \\
\hline & \multicolumn{6}{|c|}{ Nitrogen (g/tree) } \\
\hline Cultivation & $3.07 \mathrm{~b}$ & $7.25 \mathrm{~b}$ & $1.15 \mathrm{~b}$ & $7.33 \mathrm{~b}$ & $15.25 \mathrm{a}$ & $34.1 \mathrm{~b}$ \\
\hline Wood chip mulch & $5.19 \mathrm{a}$ & $13.83 \mathrm{a}$ & $5.83 \mathrm{a}$ & $20.86 \mathrm{a}$ & $14.67 \mathrm{a}$ & $59.8 \mathrm{a}$ \\
\hline \multirow[t]{2}{*}{ Legume cover } & $2.71 \mathrm{~b}$ & $5.95 \mathrm{~b}$ & $1.29 \mathrm{~b}$ & $6.25 \mathrm{~b}$ & $5.57 \mathrm{~b}$ & $21.8 \mathrm{c}$ \\
\hline & \multicolumn{6}{|c|}{ Nitrogen conch (\%) } \\
\hline Cultivation & $1.03 \mathrm{~b}$ & $0.49 \mathrm{a}$ & $1.30 \mathrm{a}$ & $2.35 \mathrm{a}$ & $0.90 \mathrm{a}$ & \\
\hline Wood chip mulch & $1.35 \mathrm{a}$ & $0.48 \mathrm{a}$ & $1.15 \mathrm{~b}$ & $2.40 \mathrm{a}$ & $0.78 \mathrm{a}$ & \\
\hline Legume cover & $1.15 \mathrm{~b}$ & $0.51 \mathrm{a}$ & $1.30 \mathrm{a}$ & $2.45 \mathrm{a}$ & $0.73 \mathrm{a}$ & \\
\hline
\end{tabular}

Table 2. Percentage of total tree dry weight and total $\mathrm{N}$ partitioned into tree components after three growing seasons (at excavation). Numbers within the same column followed by the same letter are not significantly different $(P \leq 0.05)$.

\begin{tabular}{lrrrrr}
\hline & Roots & Frame & New Growth & Leaves & Fruit \\
\cline { 2 - 6 } Treatment & \multicolumn{5}{c}{ Dry matter partitioning (\%) } \\
\hline Cultivation (CLT) & $7.8 \mathrm{a}$ & $37.8 \mathrm{~b}$ & $2.2 \mathrm{c}$ & $8.0 \mathrm{c}$ & $44.2 \mathrm{a}$ \\
Wood chip mulch (WC) & $5.6 \mathrm{~b}$ & $43.7 \mathrm{a}$ & $7.2 \mathrm{a}$ & $12.9 \mathrm{a}$ & $30.6 \mathrm{~b}$ \\
Legume cover (LC) & $8.8 \mathrm{a}$ & $45.8 \mathrm{a}$ & $4.1 \mathrm{~b}$ & $9.7 \mathrm{~b}$ & $31.6 \mathrm{~b}$ \\
& & & & \\
& & & Nitrogen partitioning (\%) \\
Cultivation & $9.1 \mathrm{~b}$ & $21.7 \mathrm{~b}$ & $3.1 \mathrm{c}$ & $21.8 \mathrm{c}$ & $44.4 \mathrm{a}$ \\
Wood chip mulch & $8.3 \mathrm{~b}$ & $22.8 \mathrm{~b}$ & $9.0 \mathrm{a}$ & $35.2 \mathrm{a}$ & $25.9 \mathrm{~b}$ \\
Legume cover & $11.6 \mathrm{a}$ & $27.1 \mathrm{a}$ & $5.3 \mathrm{~b}$ & $28.6 \mathrm{~b}$ & $24.8 \mathrm{~b}$ \\
\hline
\end{tabular}

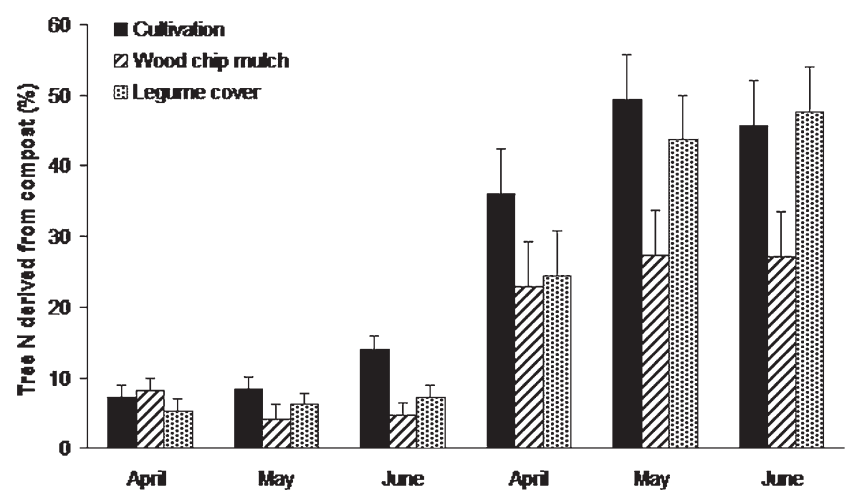

Fig. 1. Percentage of total tree N derived from compost from six application dates in 2006 and 2007 measured at excavation in Sept. 2007. Mean \pm SE $(n=3)$. 
The legume cover crop and decomposing wood chip layer represented alternative sinks for compost N. In May 2007, almost 100\% of $\mathrm{N}$ in the cover crop was derived from Aprilapplied compost (Fig. 3a). Compost $\mathrm{N}$ constituted a significantly larger portion of legume cover crop $\mathrm{N}$ in 2007 than 2006 at similar dates. In both years, NDFC of the cover crop decreased over the course of the growing season. Similarly, NDFC of the wood chip layer was greatest both years at the May sampling (Fig. 3b), but was less than the legume cover crop, ranging from $5 \%$ to $40 \%$. The total $\mathrm{N}$ content of the decomposing wood chip layer was $1.6 \%$ to $1.8 \%$, and $\mathrm{C}: \mathrm{N}$ ratio was 8.3 to 9.5 on all sampling dates (data not shown).
There was significant statistical interaction between orchard floor management and sampling date in the percentage of soil NDFC in 2006 and 2007. In 2006, NDFC in CLT soil was significantly higher than in soil under WC and LC in May, and higher than WC soils in July, while WC soil had the highest proportion of $\mathrm{N}$ derived from compost in June (Fig. 4a). In May, NDFC represented a significantly greater proportion of soil $\mathrm{N}$ than in July, followed by September. In 2007, soil $\mathrm{N}$ derived from compost did not change significantly throughout the season, and compost $\mathrm{N}$ made up a more significant portion of soil $\mathrm{N}$ in CLT soil than WC and LC plots in May, July, and September (Fig. 4b). There were no significant differences between

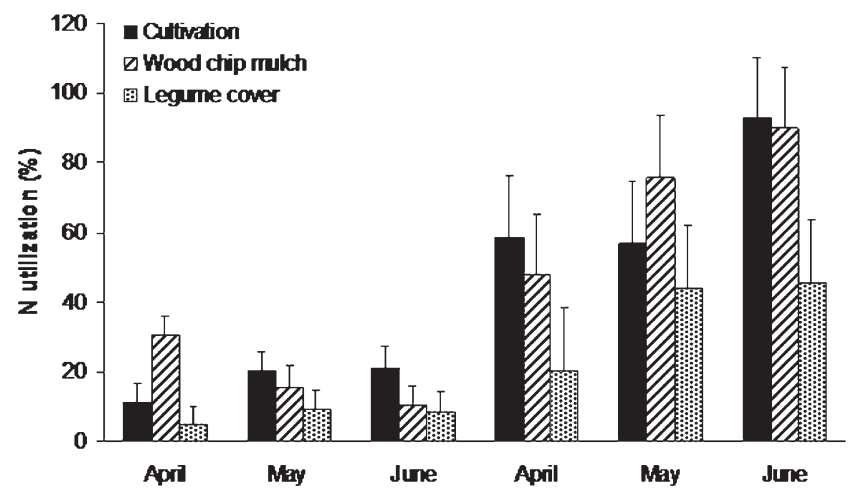

Fig. 2. Percentage of N utilization of compost N applied on six dates in 2006 and 2007 in trees measured at excavation in Sept. 2007. Mean \pm SE $(n=3)$.

Table 3. Percentage of compost derived N partitioned into tree components at time of excavation. Reserve $\mathrm{N}$ represents labeled $\mathrm{N}$ recovered from the April, May, and June 2006 compost applications, combined. Numbers within the same column followed by the same letter are not significantly different $(P \leq 0.05)$.

\begin{tabular}{lrrrrr}
\hline & Roots & Frame & New Growth & Leaves & Fruit \\
\hline Reserve N & $10.6 \mathrm{a}$ & $24.9 \mathrm{~b}$ & $5.7 \mathrm{ab}$ & $26.6 \mathrm{~b}$ & $32.1 \mathrm{~b}$ \\
Apr. 2007 & $6.2 \mathrm{~b}$ & $16.3 \mathrm{c}$ & $4.7 \mathrm{~b}$ & $31.4 \mathrm{a}$ & $41.3 \mathrm{a}$ \\
May 2007 & $10.4 \mathrm{a}$ & $31.5 \mathrm{~b}$ & $5.6 \mathrm{~b}$ & $21.9 \mathrm{c}$ & $30.6 \mathrm{~b}$ \\
June 2007 & $11.4 \mathrm{a}$ & $51.8 \mathrm{a}$ & $7.8 \mathrm{a}$ & $12.7 \mathrm{~d}$ & $16.1 \mathrm{c}$ \\
Management & & & & \\
$\quad$ Cultivation (CLT) & $8.4 \mathrm{~b}$ & $28.0 \mathrm{a}$ & $3.2 \mathrm{~b}$ & $18.5 \mathrm{c}$ & $41.9 \mathrm{a}$ \\
$\quad$ Wood chip mulch (WC) & $7.9 \mathrm{~b}$ & $32.0 \mathrm{a}$ & $9.8 \mathrm{a}$ & $28.0 \mathrm{a}$ & $22.4 \mathrm{~b}$ \\
$\quad$ Legume cover (LC) & $12.6 \mathrm{a}$ & $33.5 \mathrm{a}$ & $5.0 \mathrm{~b}$ & $23.1 \mathrm{~b}$ & $25.8 \mathrm{~b}$ \\
\hline
\end{tabular}

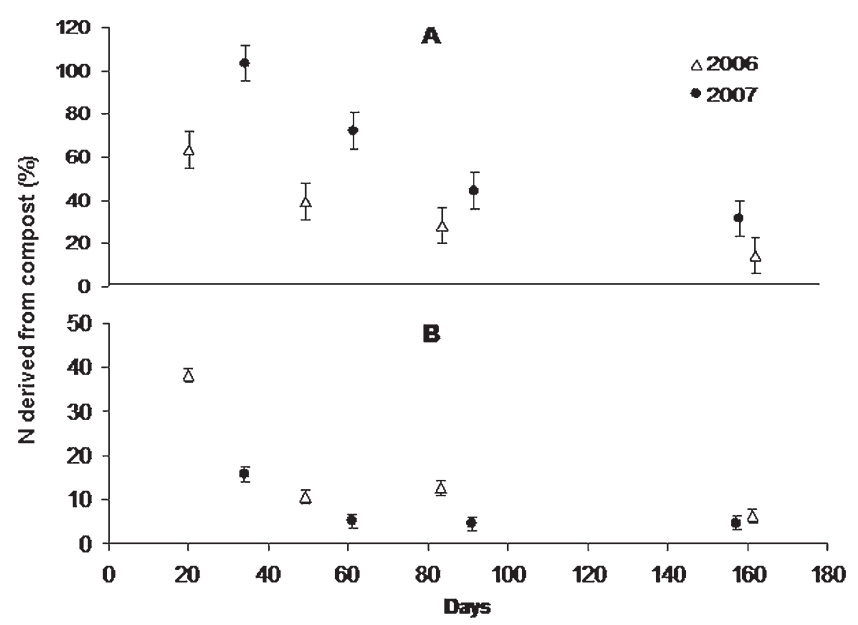

Fig. 3. N derived from compost (\%) in 2006 and 2007 in (A) legume cover crop cuttings and (B) decomposing wood chip layer, starting from Apr. 20 (Day 0). Samples taken May 9, June 7, July 13, and Sept. 29 in 2006 and May 23, June 19, July 19, and Sept. 23 in 2007. Mean \pm SE $(n=3)$.

NDFC of groundcovers/soils and ${ }^{15} \mathrm{~N}$ compost application date within sampling dates, therefore, Figs. 3 and 4 represent mean NDFC values for all three compost application dates. Orchard floor management did not significantly affect soil $\mathrm{N}$ concentration, but there was a significant increase in soil $\mathrm{N}$ in Sept. 2007 compared with other sampling dates (Fig. 5).

\section{Discussion}

The use of WC increased vegetative growth in apple trees considerably over CLT and LC trees. Decreased shoot:root ratios in CLT and LC indicate that trees were under moisture or nutrient stress (Forshey and Elving, 1989) compared with WC trees. Despite less vegetative growth in CLT trees, fruit yield was similar to WC, showing an increased fruit:vegetative growth efficiency in CLT. Preferential partitioning of dry weight and $\mathrm{N}$ into fruit in CLT may have been caused by reduced $\mathrm{N}$ uptake due to root damage or decreased N supply (Marsh et al., 1996; Sanchez et al., 2007; Yao et al., 2005). In low $\mathrm{N}$ conditions, trees may reduce the number of competing sinks for N; e.g., reduce vegetative growth (Neilsen et al., 2006). Conversely, partitioning of dry weight and $\mathrm{N}$ into the fruit of $\mathrm{WC}$ and $\mathrm{LC}$ trees was similar, suggesting that $\mathrm{N}$ availability was not the main cause of growth and yield differences between these treatments. Instead, lower root growth and increased root:shoot ratio as seen in the LC trees can signify moisture stress (Forshey and Elving, 1989), potentially reducing the photosynthetic capacity of the trees and thereby inhibiting their ability to build the carbon skeleton needed for growth.

Increased mass of perennial tissues (roots, frame, and new growth) in WC trees increased their capacity to store $\mathrm{N}$ in autumn for the subsequent growing season. Also, superior leaf growth increased the pool of $\mathrm{N}$ available for relocation into $\mathrm{N}$ reserves before leaf senescence. In this experiment, trees were excavated just after harvest; partitioning to $\mathrm{N}$ reserves at excavation was the result of $\mathrm{N}$ uptake and not translocation of $\mathrm{N}$ from leaves. Therefore, the greater $\mathrm{N}$ concentration in WC roots suggests that trees may store a larger percentage of late season $\mathrm{N}$ uptake in the roots than in CLT or LC trees.

Fruit and leaves acted as strong sinks for compost $\mathrm{N}$ early in the season-for reserve and April-applied compost N. As the season progressed, a larger percentage of $\mathrm{N}$ was allocated into perennial tissues, as vegetative growth or reserve N. These results are consistent with studies conducted using inorganic $\mathrm{N}$ sources (Munoz et al., 1993; Khemira et al., 1998; Cheng and Fuchigami, 2002).

By the time of tree excavation in Sept. 2007, NDFC and utilization of compost N applied in 2006 were low. This could be the result of lower $\mathrm{N}$ uptake, substantial loss of assimilated 2006 compost $\mathrm{N}$, and/or dilution of ${ }^{15} \mathrm{~N}$ by subsequent additions of nonenriched compost. Modes of loss of 2006 


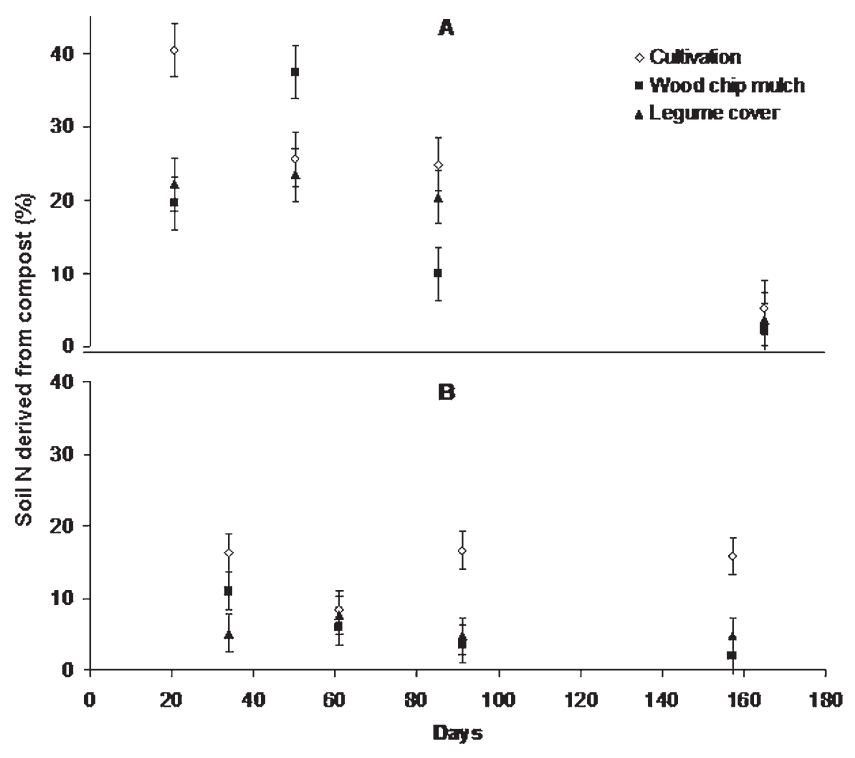

Fig. 4. Soil N derived from compost (\%) in (A) 2006 and (B) 2007, starting from Apr. 20 (Day 0). Samples taken May 9, June 7, July 13, and Sept. 29 in 2006 and May 23, June 19, July 19, and Sept. 23 in 2007. Mean \pm SE $(n=3)$.

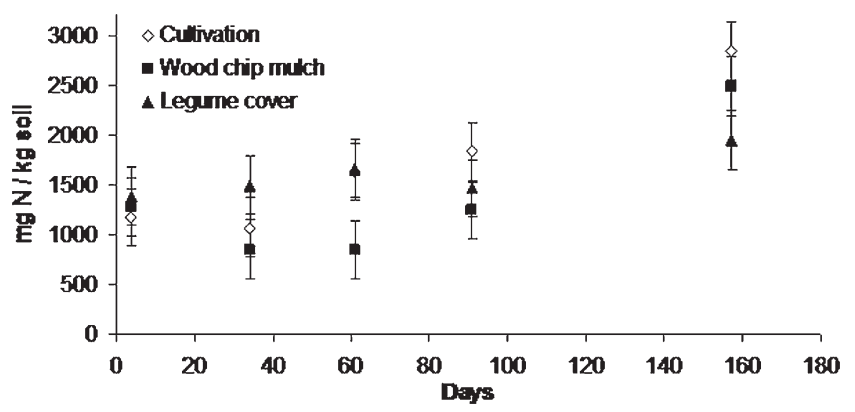

Fig. 5. Total soil $\mathrm{N}$ concentration by orchard floor management treatment over the course of the 2007 growing season, 15 to $30 \mathrm{~cm}$ from the base of each tree, starting from Apr. 20 (Day 0). Samples taken Apr. 23, May 23, June 19, July 19, and Sept. 23 in 2007. Mean \pm SE $(n=3)$.

compost $\mathrm{N}$ from trees include leaf abscission in the autumn of 2006, pruning and fruit thinning in 2007, and natural root turnover. Compost $\mathrm{N}$-use efficiency was greatest in the WC and CLT treatments, but increased $\mathrm{N}$ accumulation and lower tree NDFC indicate that trees in $\mathrm{WC}$ received a significant amount of $\mathrm{N}$ from non-compost sources. In contrast, trees under CLT and LC were more reliant on compost as an N source. Dependence on compost $\mathrm{N}$ in the LC, combined with low total tree $\mathrm{N}$, suggests that $\mathrm{N}$ fixation in the legume cover crop did not supply significant $\mathrm{N}$ to the apple trees. Nitrogen derived from compost applied in April was lower than May and June, consistent with Munoz et al. (1993), who observed peak N uptake from June to August in peach trees. Remobilization of $\mathrm{N}$ from perennial tissues may have been sufficient to meet tree $\mathrm{N}$ demands in the spring, reducing $\mathrm{N}$ uptake from fertilizer. Also, competition between apple trees and legume cover crops or the decomposing wood chip layer was greatest in the spring. In the legume cover crop treatment, bentgrass re-established quicker than the legume in 2007 (data not shown); this factor combined with cool spring tempera- tures to depress $\mathrm{N}$ fixation and increase cover crop competition for N. Cultivation incorporated $\mathrm{N}$ into the soil, increasing soil NDFC compared with soils under WC and LC. In the WC treatment, the addition of high $\mathrm{C}: \mathrm{N}$ ratio mulch in April resulted in compost $\mathrm{N}$ immobilization early in the season. We observed roots growing into the wood chip layer and hypothesize that as the season progressed, the decomposing wood chip layer shifted from a sink to source of $\mathrm{N}$, resulting in lower $\mathrm{N}$ concentration and higher $\mathrm{C}: \mathrm{N}$ ratio of the $\mathrm{WC}$ later in the season (data not shown). Water movement, diffusion, root uptake, and soil organisms helped move $\mathrm{N}$ out of the wood chips and compost and into the soil, increasing soil $\mathrm{N}$ in all treatments over the course of the growing season.

Fertilizers labeled with ${ }^{15} \mathrm{~N}$ are frequently used to track $\mathrm{N}$ uptake and movement in fruit trees, but the fertilizers used in previous studies have only been inorganic, not organic, fertilizers (Cheng and Fuchigami, 2002; Khemira et al., 1998; Millard and Neilsen, 1989; Millard and Thompson, 1989; Munoz et al., 1993; Neilsen et al., 2001a; Neilsen et al., 2001b; Toselli et al., 2000). Adding a ${ }^{15} \mathrm{~N}$-enriched $\left(\mathrm{NH}_{4}\right)_{2} \mathrm{SO}_{4}$ drench to preformed compost likely increased the amount of $\mathrm{N}$ in the labile pool compared with non-enriched compost, as well as preferentially labeling available $\mathrm{N}$ pools with ${ }^{15} \mathrm{~N}$. These factors may have altered the pattern of apparent compost $\mathrm{N}$ uptake and utilization by trees. Studies using intrinsic labeling of compost are needed to examine $\mathrm{N}$ release of more recalcitrant $\mathrm{N}$ in compost and other organic sources of $\mathrm{N}$.

This study examines the affects of orchard floor management on newly planted apple trees, which likely interact with orchard floor management treatments differently than older trees would. Vigorous tree growth in the wood chip treatment allowed young apple trees to establish quickly and yield well in the first harvest year. As the orchard matures, however, if vigorous tree growth continues, it could increase orchard management costs through increased pruning and limb training. It may be necessary, then, to complement wood chip mulch with other management strategies to reduce vegetative growth, such as deficit irrigation, reduced $\mathrm{N}$ applications, or changed timing of compost application. Otherwise, after orchard establishment, switching to a groundcover strategy that reduces tree vigor may be needed to reduce vegetative growth.

In the short term, cultivation resulted in high fruit yields despite reduced vegetative growth. Trees under cultivation were more dependent on compost for $\mathrm{N}$ than trees under wood chips, and had high fertilizer-use efficiency. However, due to the negative longterm soil impacts of cultivation on soil quality and the active soil microbial community needed to mineralize organic $\mathrm{N}$, the long-term effectiveness of this system needs further study.

The grass-legume mixture used in this study competed for moisture, reduced tree growth, fruit yield, and fertilizer-use efficiency, and absorbed significant amounts of compost N. A legume that can outcompete grasses and re-establish early in the spring may reduce competition for compost $\mathrm{N}$ and increase $\mathrm{N}$ transfer to apple trees. Legume covers have been found to improve soil microbial activity, and may be useful in established orchards (Hoagland et al., 2008). However, we conclude from this study that legume cover is unsuitable in-row groundcover for orchard establishment.

\section{Literature Cited}

Blasing, D., D. Atkinson, and K. Clayton-Greene. 1990. The contribution of roots and reserves to tree nutrient demands: Implications for the interpretation of analytical data. Acta Hort. 274:51-69.

Cambardella, C.A. and E.T. Elliot. 1992. Particulate soil organic-matter changes across a grassland cultivation sequence. Soil Sci. Soc. Amer. J. 56:777-783.

Cheng, L. and L.H. Fuchigami. 2002. Growth of young apple trees in relation to reserve nitrogen and carbohydrates. Tree Physiol. 22:12971303.

Delate, K., A. McKern, R. Turnbull, J.T. Walker, R. Volz, A. White, V. Bus, D. Rogers, L. Cole, 
N. How, S. Guernsey, and J. Johnston. 2008. Organic apple systems: Constraints and opportunities for producers in local and global markets: Introduction to the colloquium. HortScience 43:6-11.

Forge, T.A., E. Hogue, G. Neilsen, and D. Neilsen. 2003. Effects of organic mulches on soil microfauna in the root zone of apple: Implications for nutrient fluxes and functional diversity of the soil food web. Appl. Soil Ecol. 22:39-54.

Forshey, C.G. and D.C. Elving. 1989. The relationship between vegetative growth and fruiting in apple trees. Hort. Rev. (Amer. Soc. Hort. Sci.) 11:229-287.

Granatstein, D. 2004. Research directions for organic tree fruit production in North and South America. Acta Hort. 638:369-374.

Hoagland, L., L. Carpenter-Boggs, D. Granatstein, M. Mazzola, J. Smith, F. Peryea, and J.P. Reganold. 2008. Orchard floor management effects on nitrogen fertility and soil biological activity in a newly established organic apple orchard. Biol. Fertil. Soils 45:11-18.

Khemira, H., T.L. Righetti, and A.N. Azarenko. 1998. Nitrogen partitioning in apple as affected by timing and tree growth habit. J. Hort. Sci. Biotechnol. 73:217-223.

Larsson, L., B. Stenberg, and L. Torstensson. 1997. Effects of mulching and cover cropping on soil microbial parameters in the organic growing of Black Currant. Commun. Soil Sci. Plant Anal. 28(11\&12):913-925.

Marsh, K.B., M.J. Daly, and T.P. McCarthy. 1996. The effect of understory management on soil fertility, tree nutrition, fruit production and apple fruit quality. Biol. Agr. Hort. 13:161-173.

Millard, P. and C.M. Thompson. 1989. The effect of the autumn senescence of leaves on the internal cycling of nitrogen for the spring growth of apple trees. J. Expt. Bot. 40:12851289.

Millard, P. and G.H. Neilsen. 1989. The influence of nitrogen supply on the uptake and remobilization of stored $\mathrm{N}$ for the seasonal growth of apple trees. Ann. Bot. (Lond.) 63:301-309.

Munoz, N., F. Guerri, F. Legaz, and E. PrimoMillo. 1993. Seasonal uptake of $15 \mathrm{~N}$-nitrate and distribution of absorbed nitrogen in peach trees. Plant Soil 150:263-269.

Neilsen, D., G.H. Neilsen, L. Herbert, P. Millard, and S. Guak. 2006. Allocation of dry matter and $\mathrm{N}$ to fruit and shoots in dwarf apple in response to sink size and $\mathrm{N}$ availability. Acta Hort. 721:33-40.

Neilsen, D., P. Millard, G.H. Neilsen, and E.J. Hogue. 2001a. Nitrogen uptake, efficiency of use, and partitioning for growth in young apple trees. J. Amer. Soc. Hort. Sci. 126:144-150.

Neilsen, D., P. Millard, L.C. Herbert, G.H. Neilsen, E.J. Hogue, P. Parchomchuk, and B.J. Zebarth. 2001b. Remobilization and uptake of $\mathrm{N}$ by newly planted apple (Malus domestica) trees in response to irrigation method and timing of N application. Tree Physiol. 21:513-521.

Neilsen, G.H., E.J. Hogue, T. Forge, and D. Neilsen. 2003. Mulches and biosolids affect vigor, yield and leaf nutrition of fertigated high density apple. HortScience 38:41-45.

Righetti, T.L., D.R. Sandrock, B. Strik, C. Vasconcelos, Y. Moreno, S. Ortega-Farias, and P. Banados. 2007. Analysis of ratio-based responses. J. Amer. Soc. Hort. Sci. 132:3.

Sanchez, E.E., A. Giayetto, L. Cichon, D. Fernandez, M.C. Aruani, and M. Curetti. 2007. Cover crops influence soil properties and tree performance in an organic apple (Malus domestic Borkh) orchard in northern Patagonia. Plant Soil 292: 193-203.

Sanchez, E.E., T.L. Righetti, D. Sugar, and P.B. Lombard. 1992. Effects of timing of nitrogen application on nitrogen partitioning between vegetative, reproductive, and structural components of mature 'Comice' pears. J. Hort. Sci. 67:51-58

Sanchez, J.E., C.E. Edson, G.W. Bird, M.E. Whalon, T.C. Willson, R.R. Harwood, K. Kizilkaya, J.E Nugent, W. Klein, A. Middleton, T.L. Loudon, D.R. Mutch, and J. Scrimger. 2003. Orchard floor and nitrogen management influences soil and water quality and tart cherry yields. J. Amer. Soc. Hort. Sci. 128:277-284.

Shribbs, J.M. and W.A. Skroch. 1986. Influence of 12 ground cover systems on young 'Smoothee Golden Delicious' apple trees. I. Growth. J. Amer. Soc. Hort. Sci. 111:525-528.

Stiles, W. 1994. Nitrogen management in the orchard, p. 41-50. In: Peterson, A.B. and R.G. Stevens (eds.). Tree fruit nutrition shortcourse proceedings. Good Fruit Grower, Yakima.

Titus, J.S. and S.M. Kang. 1982. Nitrogen metabolism, translocation, and recycling in apple trees. Hort. Rev. (Amer. Soc. Hort. Sci.) 4: 204-246.

Toselli, M., J.A. Flore, C. Zavalloni, and B. Marangoni. 2000. Nitrogen partitioning in apple trees as affected by application time. HortTechnology 10:136-141.

Yao, S., I.A. Merwin, G.W. Bird, G.S. Abawi, and J.E. Thies. 2005. Orchard floor management practices that maintain vegetative or biomass groundcover stimulate soil microbial activity and alter soil microbial community composition. Plant Soil 271:377-389. 